\title{
COMPOSITION OF ADVANCES IN THE DISTRICT CENTRAL COOPERATIVE BANKS IN PUNJAB \\ PRIYA GOEL*
}

\author{
Research Scholar, Kumar Bhaskar Varma Sanskrit and Ancient Studies University, Assam" \\ ** Dr. Devender Pathak, Vice Chancellor, KN Modi University, Rajasthan"
}

\section{ABSTRACT}

The Banking scene in India has undergone a tremendous change due to the Narsimham Committee recommendations since 1992 i.e. with the advent of the new economic policy. It emphasized shift from centralized planning to indicative planning. Thus the committee shifted its onus from ownership to efficiency and competitiveness while ensuring the integrity and operational autonomy of the banks. Financial sector reforms, based on Narsimham committee recommendations, aim at fostering financially strong banking cooperative in a competitive world.

As a result of these financial sector developments, policy makers and social thinkers were apprehensive that cooperative banking sector will be facing the challenges of increasing competition, emerging opportunities and withdrawal of government support and may have to abandon its social objectives. But cooperative banking system has some inherent strength in the form of its reach, infrastructure and intimate relations with its customers which have strengthened these banks to make a vital contribution to nation's development. Cooperative banking system has progressively matured and is preparing itself to successfully meet new challenges.

This paper is focused on one of the main business areas of the District Central Cooperative Banks of Punjab i.e. composition of advances. In this paper, a brief outline has been given about the various loan schemes of the District Central Cooperative Banks and the total loans outstanding in different categories of loans advanced during the period of study i.e. from 2000 to 2010.

\section{Council for Innovative Research}

Peer Review Research Publishing System

\section{Journal: International Journal Of Management \& Information Technology}

Vol. 10, No 7

editorsijmit@gmail.com

www.ijmit.com 


\section{INTRODUCTION}

Cooperative banks, basically, were established as a tool of government policy, to provide institutional credit to farmers at lower rates and easy terms. Cooperative Agricultural Development Banks were providing long term credit to farmers for capital formation i.e. purchase of tractors, agricultural implements or land reclamation, tube well pumping etc. Similarly District Cooperative Banks were providing short-term credit facilities to farmers for purchase of agriculture inputs. These banks were even known as 'Society Banks' or Kissan Banks'. As a result of financial sector reforms, cooperative banks had to face a stiff competition, banking technology explosion, new prudential banking norms, customer central banking operations and a deregulated and market oriented banking system. And in response, these banks had to redefine and refine their working culture and working strategy. Cooperative banks responded to above banking challenges with full vigour and strength. Sound banking practices replaced the age-old credit agency system approach. They adopted professional approach to control the costs and enhance the yield. Being committed to economic upliftment of rural masses, they have to provide timely and adequate credit at cheaper rates to farming community. To meet this social obligation, they have to earn from somewhere. To supplement the low yield assets, these banks had only one choice i.e. diversification in high yield areas. Once allowed to go in prohibited areas, these banks have created a niche for themselves in non-farm sector operations.

Since 1992, these banks have diversified business operations in financing non-farm sector activities and during the last few years, the cooperative banks have witnessed a phenomenal change in terms of variety in its business products. Now, these banks are not only confined to agricultural credit business. The thrust of loan portfolio of these banks has shifted from agriculture credit to general advancement, which covers non-agriculture and other high yield advances also.

\section{RESEARCH DESIGN}

The sample of the study was based on multi-stage stratified random sampling technique. Three agro-climatic zones became the $1^{\text {st }}$ stage of sampling design. Two District Central Cooperative Banks (DCCBs) were randomly selected from each zone.

\section{A) Trend Analysis}

In order to assess the existing trends and to estimate the future trends in different parameters under study, trend analysis was performed in two forms.

\section{(i) Compound Growth Rates}

The compound growth rates of different types of loans outstanding and NPAs thereof, in the DCCBs were worked out by applying the regression model in its exponential form as under:

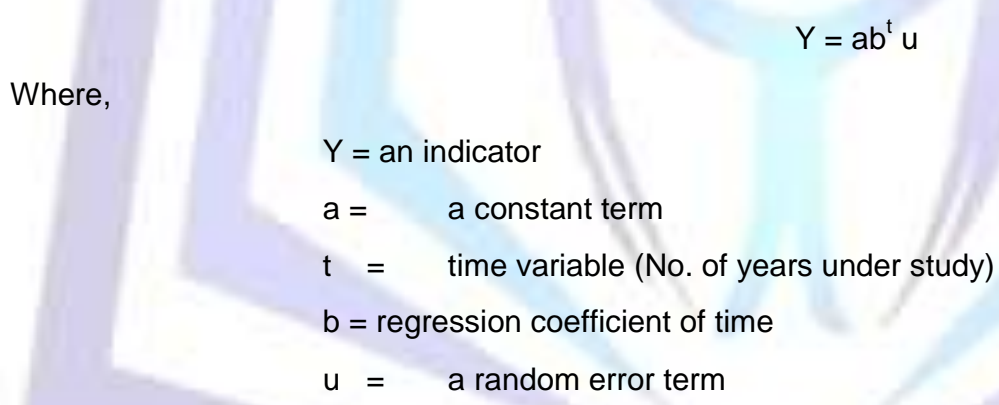

Log transformation of the above function is:

$$
\ln Y_{t}=\ln a+t(\ln b)+e
$$

Where,

$$
\begin{aligned}
& \ln b=\quad \ln (1+r) \text { and } \\
& r=\quad[\operatorname{antilog}(\ln b)-1] \times 100 \\
& \operatorname{CGR}(\%)=\quad[\text { antilog }(\ln b)-1] \times 100
\end{aligned}
$$

The compound growth rates were tested to determine their statistical significance with the help of t-test.

\section{(ii) Trend Equation}

To make future projections of different indicators, trend equations were developed in the form of linear regression as under:

$$
\mathrm{Y}=\mathrm{a}+\mathrm{bt}+\mathrm{u}
$$

Where,

$$
\mathrm{Y}=\text { a performance indicator }
$$




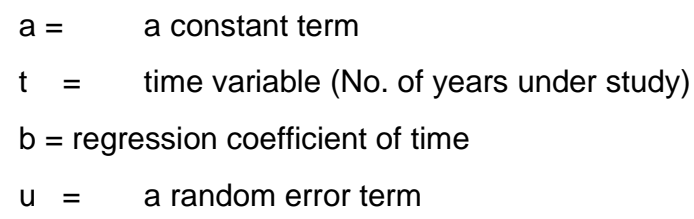

Then the coefficient of ' $a$ ' and 'b' were used to make future projections for the year 2015-2016 and 2020-2021.

\section{THE VARIOUS LOAN SCHEMES OF THE DCCBS ARE:}

\section{1: CROP LOAN}

Crop loan is a short-term loan advanced to farmers for the purpose of enabling them to buy seeds, fertilizer and pesticides. It is distributed to farmers through Primary Agriculture Cooperative Societies (PACSS). Maximum loan, which a farmer can get under this scheme, depends upon his land holding, and scale of finance for each crop which is fixed by an expert committee constituted by the government.

\section{2: REVOLVING CASH CREDIT LIMIT TO FARMERS (RCCL (F)}

Money in this scheme is advanced to meet the socio- economic needs of the farmers, , on the basis of their land holding, A withdrawal limit is fixed for the farmer, upto a maximum of Rs. 300,000, which has been enhanced to Rs. 600,000 since $1^{\text {st }}$ July, 2007. He can withdraw and deposit money any number of times, depending upon his requirement. Limit is sanctioned initially for a period of one year, renewable subject to satisfactory operation in the account.

\section{3: NON FARM SECTOR (NFS)}

In 1996-97, NABARD encouraged the cooperative banks to diversify their activities and started providing refinance for lending to the non farm sector (NFS). From 1996-97, DCCBs are advancing loans for various purposes under non farm sector, which includes Integrated Loan Scheme, Composite Scheme and Small Road and Water Transport Operators loan (SRWTO) Scheme. Under Integrated Loan Scheme, the loan is advanced to any individual, partnership firms, corporate bodies, companies, small entrepreneurs etc. to establish or extend any manufacturing service and processing unit as approved by KVIC/ NABARD, up to a maximum of 75percent of the project cost minus cost of land. Under the Composite Loan Scheme, the loan is advanced to individuals and small entrepreneurs to establish or extend any manufacturing service and processing unit as approved by KVIC/NABARD, upto a maximum of Rs. 10 lakhs or 75 percent of the project cost minus cost of land, whichever is less. Under SRTO Scheme, the loan is advanced for the purchase of a new vehicle to be used for commercial purposes i.e., trucks, mini trucks, bus, auto rickshaw, water transport units etc upto a maximum amount of Rs. $10,00,000$.

\section{4: CONSUMER DURABLE LOAN}

In this scheme, loan is advanced to individuals whether in service or self employed for purchase of consumer durables. Maximum limit per loanee under this scheme is Rs.50, 000.

\section{5: VEHICLE LOAN}

This loan is advanced to provide financial assistance for purchasing a new vehicle for business or personal use to any individual, group of individuals or a partnership firm. Amount of loan, which can be advanced under this scheme is Rs. 600,000 or 80 percent of the value of the vehicle, whichever is less.

\section{6: CASH CREDIT LIMIT (TRADERS)}

Cash credit limit is a short term financing scheme. Only traders, government/quasi government contractors, registered units run by the self employed persons and professionals like doctors, engineers lawyers etc. are allowed finance under this scheme for a period of one year to meet their working capital requirements. Depending upon the turnover of the trader, an overdraft limit is fixed, upto which the trader can withdraw or deposit money any number of times in the account. At the end of one year, the trader will be required to get his limit renewed. Maximum loan advanced under this scheme per person is Rs. 15 lacs.

\section{7: OTHER LOANS}

This Category includes Personal loans, Housing Loans (Rural and Urban), Education Loans and other loans advanced for consumption purposes.

\subsection{1: PERSONAL LOANS}

Under this scheme, loan is advanced by the bank to meet socio-economic needs of employees such as child's education, furnishing house, buying a computer, son's/daughter's marriage, holiday tour etc i.e. it is not a productive loan. Only salaried employees of Punjab Government, Cooperative Department, and Punjab State Cooperative Bank are eligible for loan in this scheme as per the bank norms. Amount of loan, which can be advanced under this scheme to one individual, is Rs. 200,000 or 10 months gross salary, which ever is less. 


\subsection{2: HOUSING LOANS}

Housing loan is one of the most saleable bank products. Main reasons for this are great desire of the people to own houses and income tax incentives on housing loans. Cooperative banks, in the year 2003-04, launched two different housing loan schemes for urban and rural clients. Maximum credit, which can be availed by a loanee from urban area is Rs. 10 lacs, whereas a rural area client can avail a maximum of Rs. 5 lacs under this scheme.

\subsection{3: EDUCATION LOAN}

This loan is advanced to provide financial assistance to students with at least 50 percent marks in +2 , for pursuing higher studies in India or Abroad i.e. Engineering, Medical, Dental, Law, Computer, Agriculture ICWA, CA etc or any other course run by a recognized university. The maximum amount of loan is Rs. 500,000 for studies in India and Rs. 10, 00,000 for studies abroad for a maximum period of 5 years.

It is felt that a serious attempt is required to assess the quantum of loans outstanding in different banks. The quantum of loans outstanding depends upon two things:

a) Efficient advancement

b) Ineffective recoveries

If the loans outstanding increase due to new advances, it is a healthy sign for the banks but if the loans outstanding show a rising trend due to improper recoveries, then the financial position of the banks is not sound. By and large, the efficiency of the DCCBs can be assessed taking into account their performance in mobilizing adequate internal resources and meeting credit needs of the area (CRAFICARD, 1978).

\section{COMPOSITION OF ADVANCES IN THE DISTRICT CENTRAL COOPERATIVE BANKS IN PUNJAB}

The trends in advances outstanding, future projections and trends in proportionate share of different types of advances outstanding in the selected DCCBs, have been discussed

\section{DISTRICT CENTRAL COOPERATIVE BANKS IN ZONE-I}

\section{Zone-I}

THE NAWANSHAHR CENTRAL COOPERATIVE BANK LTD, NAWANSHAHR

The trends and future projections for different types of loans outstanding in DCCB, Nawanshehar are presented in Table 5.1.

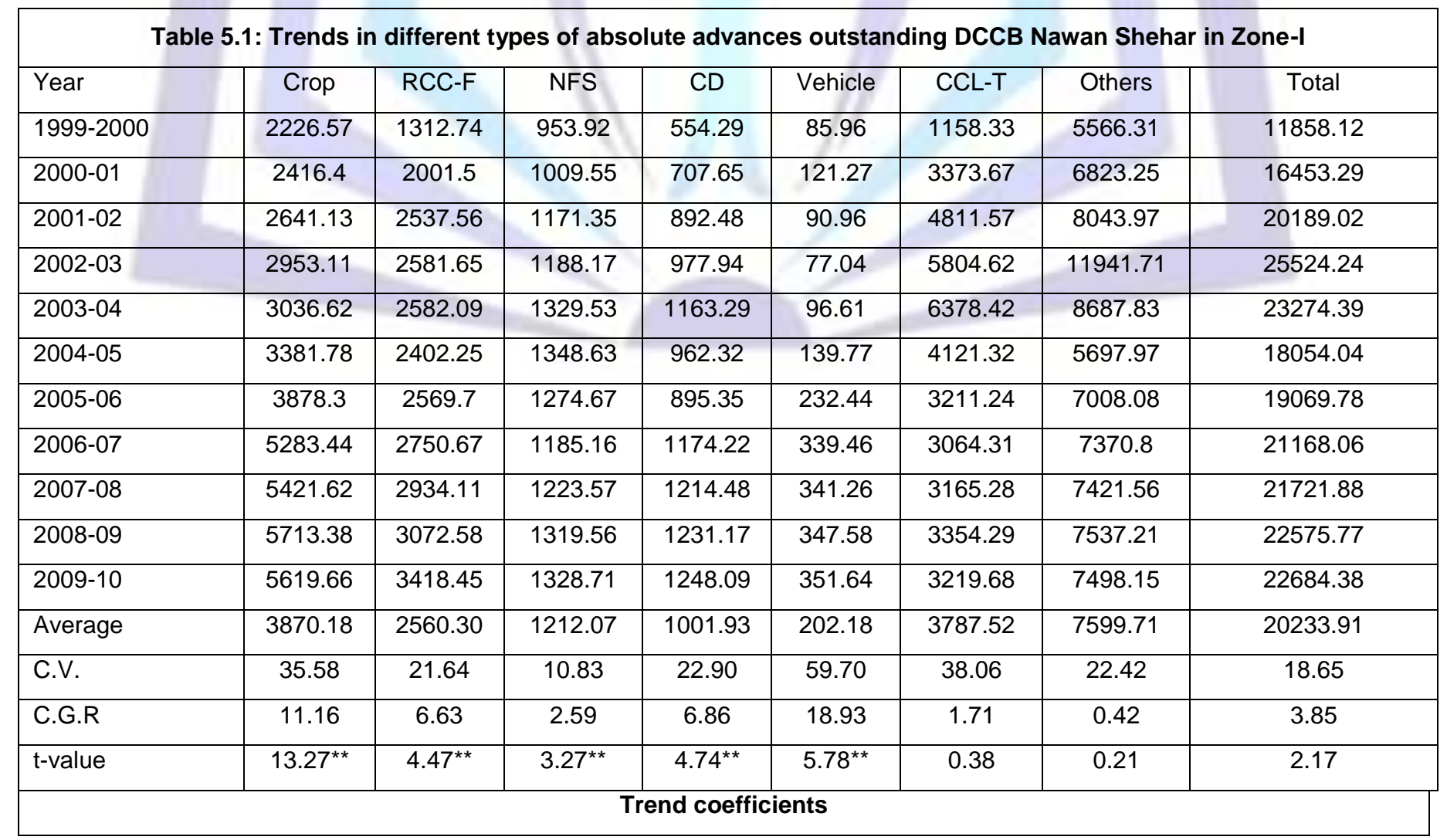




\begin{tabular}{|l|c|c|c|c|c|c|c|c|} 
A & 1470.34 & 1669.67 & 1037.00 & 639.01 & 3.35 & 3970.65 & 7609.19 & 16399.21 \\
\hline B & 399.97 & 148.44 & 29.18 & 60.49 & 33.14 & -30.52 & -1.58 & 639.12 \\
\hline Future Projections & & & & & & & & \\
\hline $2015-16$ & 8269.83 & 4193.15 & 1533.06 & 1667.34 & 566.73 & 3451.81 & 7582.33 & 27264.25 \\
\hline $2020-21$ & 10269.68 & 4935.35 & 1678.96 & 1969.79 & 732.43 & 3299.21 & 7574.43 & 30459.85 \\
\hline $\begin{array}{l}\text { \%change over } \\
2009-10\end{array}$ & & & & & & & & \\
\hline $2015-16$ & 47.16 & 22.66 & 15.38 & 33.59 & 61.17 & 7.21 & 1.12 & 20.19 \\
\hline $2020-21$ & 82.75 & 44.37 & 26.36 & 57.82 & 108.29 & 2.47 & 1.02 & 34.28 \\
\hline
\end{tabular}

It is first time encouraging to note that the total loans outstanding in DCCB, Nawanshehar increased at an insignificant rate. This indicated that the outstanding in the bank neither increased nor decreased, rather these were stagnant over 2000-2010. Similarly, the insignificant growth in CCL(T) and other loans outstanding were found to be in correspondence with the trends in total loans outstanding The highest significant positive growth could be seen in case of vehicle loan outstanding i.e, 18.93 percent per annum, followed by 11.16 percent in case of crop loan, 6.86 percent in case of consumer durable loans and 6.63 percent for RCCL (F) while the lowest growth rate to the tune of 2.59 percent was found to be in case of non-farm sector loans outstanding.

Though, total loans outstanding would increase in future but insignificantly. Similar would be the trend in case of $C C L(T)$ and other loans outstanding. However, there would be an increase of 47.16 percent in crop loan outstanding in 2016 over 2010. Similarly the outstanding in RCCL (F), non-farm sector loans, consumer durable loan and vehicle loan would also increase in future. Therefore, there is a large scope of improvement in DCCB, Nawanshehar.

Trends in Proportionate Share of Different Types of Advances Outstanding:

Table 5.2: Trends in proportionate share of different types of advances outstanding in DCCB Nawan Shehar in Zone-I

\begin{tabular}{|c|c|c|c|c|c|c|c|c|}
\hline Year & Crop & $\begin{array}{c}\text { RCC- } \\
\text { F }\end{array}$ & NFS & CD & Vehicle & $\begin{array}{c}\text { CCL- } \\
\mathrm{T}\end{array}$ & Others & Total \\
\hline $1999-2000$ & 18.78 & 11.07 & 8.04 & 4.67 & 0.72 & 9.77 & 46.94 & 100 \\
\hline $2000-01$ & 14.69 & 12.16 & 6.14 & 4.30 & 0.74 & 20.50 & 41.47 & 100 \\
\hline $2001-02$ & 13.08 & 12.57 & 5.80 & 4.42 & 0.45 & 23.83 & 39.84 & 100 \\
\hline $2002-03$ & 11.57 & 10.11 & 4.66 & 3.83 & 0.30 & 22.74 & 46.79 & 100 \\
\hline 2003-04 & 13.05 & 11.09 & 5.71 & 5.00 & 0.42 & 27.41 & 37.33 & 100 \\
\hline 2004-05 & 18.73 & 13.31 & 7.47 & 5.33 & 0.77 & 22.83 & 31.56 & 100 \\
\hline $2005-06$ & 20.34 & 13.48 & 6.68 & 4.70 & 1.22 & 16.84 & 36.75 & 100 \\
\hline 2006-07 & 24.96 & 12.99 & 5.60 & 5.55 & 1.60 & 14.48 & 34.82 & 100 \\
\hline $2007-08$ & 24.96 & 13.51 & 5.63 & 5.59 & 1.57 & 14.57 & 34.17 & 100 \\
\hline 2008-09 & 25.31 & 13.61 & 5.85 & 5.45 & 1.54 & 14.86 & 33.39 & 100 \\
\hline $2009-10$ & 24.77 & 15.07 & 5.86 & 5.50 & 1.55 & 14.19 & 33.05 & 100 \\
\hline Average & 19.11 & 12.63 & 6.13 & 4.94 & 0.99 & 18.37 & 37.83 & 100 \\
\hline C.V. & 28.19 & 11.28 & 15.40 & 12.09 & 52.09 & 29.36 & 14.14 & \\
\hline C.G.R. & 7.04 & 2.68 & -1.21 & 2.91 & 14.54 & -2.06 & -3.30 & \\
\hline t-value & 3.36 & $3.43^{* *}$ & 0.85 & $3.43^{\star *}$ & $3.12^{*}$ & 0.70 & $4.27^{\star \star}$ & \\
\hline \multicolumn{8}{|c|}{ Future Projections } & \\
\hline $2015-16$ & 30.33 & 15.38 & 5.62 & 6.12 & 2.08 & 12.66 & 27.81 & \\
\hline $2016-20$ & 33.72 & 16.20 & 5.51 & 6.47 & 2.40 & 10.83 & 24.87 & \\
\hline
\end{tabular}


Table 5.2 revealed that, on the average the highest proportion i.e. 37.83 percent of total loans outstanding was secured by other loans such as housing loan and personal loan outstanding in Nawanshehar bank. It could also be established that these outstanding are not going to increase in future according to the existing trend. Similarly the second major proportion i.e. 19.11 percent was accounted for by Crop loan and this too would not increase in future. Thus, it is encouraging to say that about 60 percent of the total loans outstanding would not increase in future. The remaining 40 percent of outstanding would increase and hence it provides bright avenues of improvements in DCCB, Nawanshehar.

THE JALANDHAR CENTRAL COOPERATIVE BANK LTD, JALANDHAR

Table 5.3: Trends in different types of absolute advances outstanding in DCCB Jalandhar in Zone-I

\begin{tabular}{|c|c|c|c|c|c|c|c|c|}
\hline Year & Crop & RCC-F & NFS & CD & Vehicle & CCL-T & Others & Total \\
\hline $1999-2000$ & 4452.94 & 1777.36 & 519.22 & 1550.89 & 170.03 & 895.34 & 10487.96 & 19853.74 \\
\hline $2000-01$ & 4591.29 & 2996.75 & 679.76 & 1773.58 & 157.7 & 1140.97 & 10608.55 & 21948.6 \\
\hline 2001-02 & 4905.01 & 3809.26 & 825.04 & 2096.26 & 268.4 & 1347.71 & 13715.82 & 26967.5 \\
\hline $2002-03$ & 5766.07 & 4427.23 & 1026.89 & 2288.74 & 401.02 & 1323.7 & 24098.83 & 39332.48 \\
\hline 2003-04 & 5893.78 & 4796.78 & 1435.23 & 2767.76 & 499.24 & 1432.95 & 17883.74 & 34709.48 \\
\hline 2004-05 & 6478.66 & 4504.75 & 1718.74 & 2839.73 & 600.89 & 1354.44 & 11468.22 & 28965.43 \\
\hline 2005-06 & 7204.33 & 5131.09 & 1950.51 & 2842.49 & 750.66 & 1292.44 & 8661.87 & 27833.39 \\
\hline 2006-07 & 9728.34 & 5533 & 2046.88 & 2483.58 & 1235.79 & 1348.86 & 11157.28 & 33533.73 \\
\hline 2007-08 & 9934.52 & 5661.19 & 2163.58 & 2621.62 & 1441.28 & 1428.92 & 11457.23 & 34708.34 \\
\hline 2008-09 & 10123.55 & 5823.12 & 2234.18 & 2519.18 & 1335.19 & 1537.84 & 11982.34 & 35555.4 \\
\hline $2009-10$ & 9823.15 & 5925.14 & 2459.36 & 2637.12 & 1453.27 & 1567.45 & 11735.19 & 35600.68 \\
\hline Average & 7172.88 & 4580.52 & 1550.85 & 2401.90 & 755.77 & 1333.69 & 13023.37 & 30818.98 \\
\hline C.V. & 32.15 & 28.27 & 44.39 & 18.00 & 68.45 & 13.97 & 33.39 & 20.04 \\
\hline C.G.R & 10.00 & 9.90 & 16.83 & 4.57 & 27.79 & 3.80 & -1.58 & 4.71 \\
\hline t-value & $11.70^{* *}$ & $4.98^{* *}$ & $9.27^{* *}$ & $3.27^{* *}$ & $11.63^{\star \star}$ & $3.91^{* \star}$ & 0.58 & $2.90^{*}$ \\
\hline \multicolumn{9}{|c|}{ Trend coefficients } \\
\hline A & 3174.49 & 2390.73 & 324.17 & 1831.68 & -147.82 & 1055.43 & 14669.40 & 23298.08 \\
\hline B & 666.40 & 364.96 & 204.45 & 95.04 & 150.60 & 46.38 & -274.09 & 1253.74 \\
\hline \multicolumn{9}{|c|}{ Future Projections } \\
\hline $2015-16$ & 14503.29 & 8595.05 & 3799.82 & 3447.36 & 2412.38 & 1843.89 & 10009.87 & 44611.66 \\
\hline $2020-21$ & 17835.29 & 10419.85 & 4822.07 & 3922.56 & 3165.38 & 2075.79 & 8639.42 & 50880.36 \\
\hline \multicolumn{9}{|c|}{ \%change over 2009-10 } \\
\hline $2015-16$ & 47.64 & 45.06 & 54.50 & 30.72 & 66.00 & 17.64 & -14.70 & 25.31 \\
\hline $2020-21$ & 81.56 & 75.86 & 96.07 & 48.74 & 117.81 & 32.43 & -26.38 & 42.92 \\
\hline
\end{tabular}

The analysis shown in Table 5.3 indicated that total loans outstanding in DCCB, Jalandhar increased from Rs. 19853.74 lakh in 2000 to Rs. 35600.68 lakh in 2010 at a significant rate of 4.71 percent per annum. All types of loans outstanding, except other loans, increased significantly. The highest growth rate i.e. 27.79 percent was witnessed in vehicle loans outstanding, followed by 16.83 percent in NFS and 10.00 percent in crop loan. The lowest growth rate i.e., 3.80 percent was seen in CCL (T) followed by 4.57 percent in $C D$ loans. Based on the existing trend, the outstanding in crop loan, RCCL(F), non-farm sector loan, consumer durable loans, vehicle loans and $\operatorname{CCL}(T)$ would further increase in future but the largest volume of outstanding i.e. other loans outstanding would remain constant, rather somewhat decline could be seen. Thus, overall outstanding would not increase significantly in future in DCCB, Jalandhar. Thus, the bank should particularly focus on the recovery of other loans outstanding.

Table 5.4: Trends in proportionate share of different types of advances outstanding in DCCB Jalandhar in Zone-I 


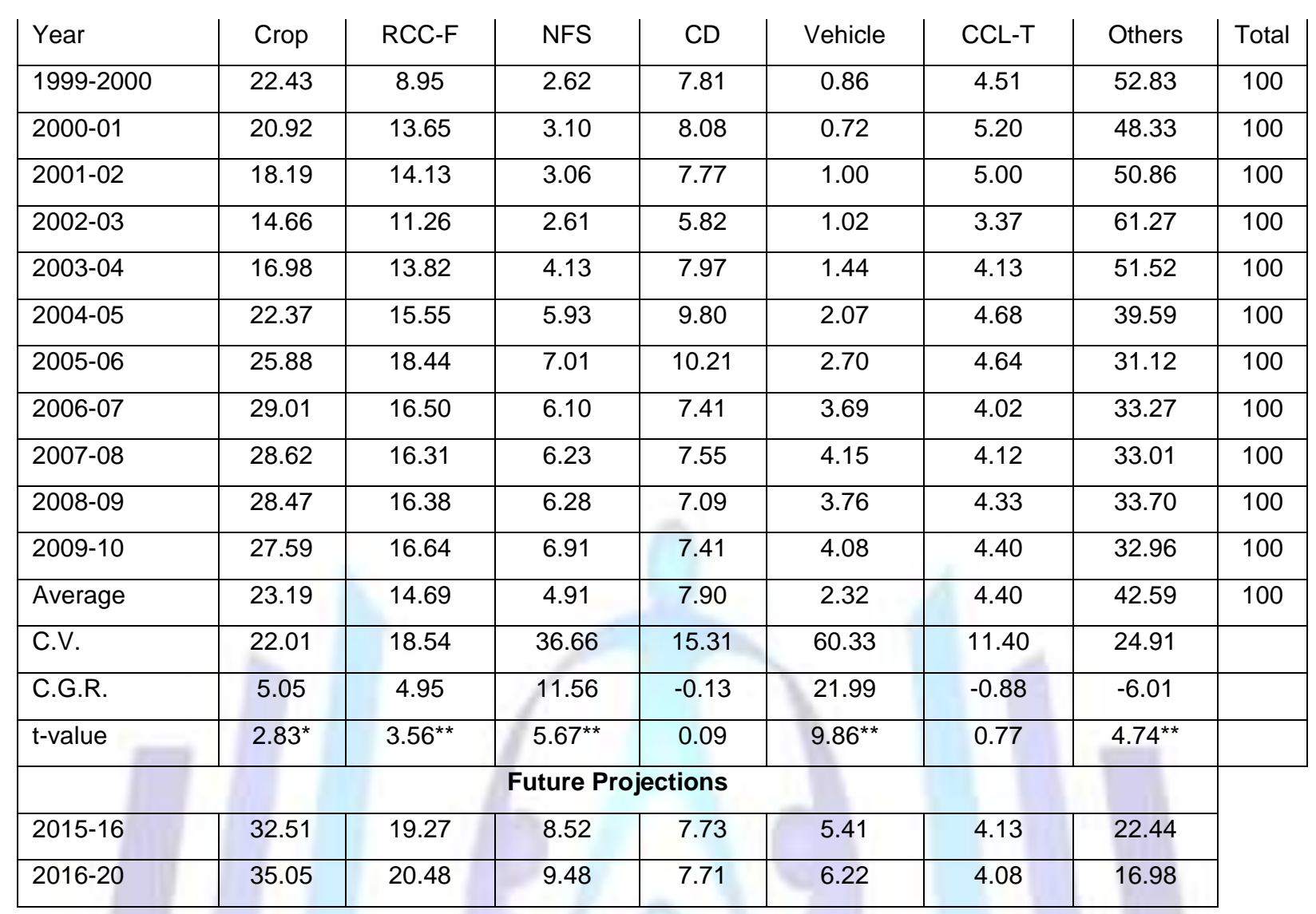

The analysis shown in table 5.4 showed that the share of crop loan, RCC-F, NFS loans, CD loans and vehicle loans increased significantly from 1999-2000 to 2009-10. On the other hand, there was a significant decline in the share of other loans while stagnation could be seen in case of CCL-T. The results reaffirmed that the share of other loans outstanding which secured 42.59 percent on the average, would decline to 4.13 percent in 2016. Similar is the pattern in case of CCL-T which would decline significantly from 4.40 percent in 2009-10 to 5.41 percent in 2015-16. Their shares would be shifted to crop loan, RCC-F, NFS, CD loans and vehicle loans. Therefore, it can be said that DCCB, Jalandhar is in a better position than other banks in case of advances outstanding

\section{ZONE-II}

THE AMRITSAR CENTRAL COOPERATIVE BANK LTD, AMRITSAR

\begin{tabular}{|l|c|c|c|c|c|c|c|c|}
\hline \multicolumn{7}{|c|}{ Table 5.5: Trends in different types of absolute advances outstanding in DCCB Amritsar in Zone-II } \\
\hline Year & Crop & RCC-F & NFS & CD & Vehicle & CCL-T & Others & Total \\
\hline $1999-2000$ & 5155.29 & 1816.73 & 449.17 & 1712.91 & 584.22 & 203.82 & 2577.65 & 12499.79 \\
\hline $2000-01$ & 5775.07 & 2717.91 & 677.56 & 1705.19 & 834.76 & 294.42 & 3632.49 & 15637.4 \\
\hline $2001-02$ & 6920.18 & 3628.36 & 1040.97 & 2047.02 & 945.85 & 393.32 & 3902.77 & 18878.47 \\
\hline $2002-03$ & 8448.48 & 4192.61 & 1500.19 & 2457.12 & 917.8 & 428.72 & 4387.13 & 22332.05 \\
\hline $2003-04$ & 9393.87 & 4303.18 & 1749.68 & 2782.03 & 941.09 & 498.75 & 5666.14 & 25334.74 \\
\hline $2004-05$ & 10923.26 & 4304.24 & 1804.38 & 2690.23 & 1013.72 & 475.78 & 5480.25 & 26691.86 \\
\hline $2005-06$ & 12778.26 & 4296.68 & 1773.03 & 2371.32 & 994.49 & 466.17 & 5357.07 & 28037.02 \\
\hline $2006-07$ & 15256.59 & 4137.92 & 1769.3 & 2185.71 & 880.57 & 534.52 & 6112.79 & 30877.4 \\
\hline $2007-08$ & 16134.11 & 4256.67 & 1756.23 & 2254.41 & 889.23 & 581.13 & 6218.25 & 32090.03 \\
\hline $2008-09$ & 16248.55 & 4261.24 & 1798.25 & 2267.25 & 916.25 & 604.25 & 6324.11 & 32419.9 \\
\hline $2009-10$ & 17327.41 & 4168.92 & 1814.21 & 2298.67 & 834.11 & 614.19 & 6298.26 & 33355.77 \\
\hline
\end{tabular}




\begin{tabular}{|c|c|c|c|c|c|c|c|c|}
\hline Average & 11305.55 & 3825.86 & 1466.63 & 2251.99 & 886.55 & 463.19 & 5086.99 & 25286.77 \\
\hline C.V. & 39.69 & 21.40 & 34.33 & 15.17 & 13.01 & 27.73 & 25.02 & 28.23 \\
\hline C.G.R & 13.81 & 5.99 & 12.34 & 2.30 & 1.78 & 9.45 & 8.22 & 9.68 \\
\hline $\mathrm{t}$-value & $15.37^{\star \star}$ & $2.89^{\star}$ & $3.83^{\star \star}$ & 1.62 & 1.27 & $5.78^{\star \star}$ & $6.07^{\star \star}$ & $8.13^{\star \star}$ \\
\hline \multicolumn{9}{|c|}{ Trend coefficients } \\
\hline A & 3265.72 & 2751.13 & 702.16 & 1987.68 & 811.04 & 243.17 & 2934.73 & 12695.63 \\
\hline B & 1339.97 & 179.12 & 127.41 & 44.05 & 12.59 & 36.67 & 358.71 & 2098.52 \\
\hline \multicolumn{9}{|c|}{ Future Projections } \\
\hline 2015-16 & 26045.21 & 5796.17 & 2868.13 & 2736.53 & 1025.07 & 866.56 & 9032.80 & 48370.47 \\
\hline $2020-21$ & 32745.06 & 6691.77 & 3505.18 & 2956.78 & 1088.02 & 1049.91 & 10826.35 & 58863.07 \\
\hline \multicolumn{9}{|c|}{ \%change over 2009-10 } \\
\hline 2015-16 & 50.31 & 39.03 & 58.09 & 19.05 & 22.89 & 41.09 & 43.42 & 45.01 \\
\hline $2020-21$ & 88.98 & 60.52 & 93.21 & 28.63 & 30.44 & 70.94 & 71.89 & 76.47 \\
\hline
\end{tabular}

The analysis given in Table 5.5 showed that total loans outstanding in DCCB, Amritsar increased from Rs. 12499.79 lacs in 2000 to Rs. 33355.77 lacs in 2010, registering a highly significant compound growth of 9.68 per cent per annum. All types of advances outstanding, except CD loans and vehicle loans, increased significantly in DCCB, Amritsar during 2000 to 2010. The growth rate was found to be highest in case of outstanding crop loans (13.81 percent), followed by non-farm sector loans (12.34 percent), CCL-T (9.45 percent), other loans ( 8.22 percent) and RCCL-F (5.99 percent).

Keeping in view the existing trend of increase in all types of loans outstanding, it is estimated that total loans outstanding in DCCB, Amritsar would increase from Rs. 33355.77 lacs in 2010 to Rs.48370.47 lacs in 2016 i.e. an increase of 45.10 percent over 2010 and further to Rs. 58863.07 lacs in 2021 i.e. an increase of 76.47 percent over 2010. According to the quantum and significant level of growth rates, it may be estimated that in future, growth of outstanding in consumer durable loans and vehicle loans would be slower than that in other types of loans. Therefore, the bank should take appropriate steps to curb the increasing trend in advances outstanding.

\begin{tabular}{|c|c|c|c|c|c|c|c|c|}
\hline Year & Crop & RCC-F & NFS & CD & Vehicle & CCL-T & Others & Total \\
\hline $1999-2000$ & 41.24 & 14.53 & 3.59 & 13.70 & 4.67 & 1.63 & 20.62 & 100 \\
\hline $2000-01$ & 36.93 & 17.38 & 4.33 & 10.90 & 5.34 & 1.88 & 23.23 & 100 \\
\hline $2001-02$ & 36.66 & 19.22 & 5.51 & 10.84 & 5.01 & 2.08 & 20.67 & 100 \\
\hline $2002-03$ & 37.83 & 18.77 & 6.72 & 11.00 & 4.11 & 1.92 & 19.64 & 100 \\
\hline 2003-04 & 37.08 & 16.99 & 6.91 & 10.98 & 3.71 & 1.97 & 22.37 & 100 \\
\hline 2004-05 & 40.92 & 16.13 & 6.76 & 10.08 & 3.80 & 1.78 & 20.53 & 100 \\
\hline $2005-06$ & 45.58 & 15.33 & 6.32 & 8.46 & 3.55 & 1.66 & 19.11 & 100 \\
\hline $2006-07$ & 49.41 & 13.40 & 5.73 & 7.08 & 2.85 & 1.73 & 19.80 & 100 \\
\hline 2007-08 & 50.28 & 13.26 & 5.47 & 7.03 & 2.77 & 1.81 & 19.38 & 100 \\
\hline 2008-09 & 50.12 & 13.14 & 5.55 & 6.99 & 2.83 & 1.86 & 19.51 & 100 \\
\hline $2009-10$ & 51.95 & 12.50 & 5.44 & 6.89 & 2.50 & 1.84 & 18.88 & 100 \\
\hline Average & 43.45 & 15.51 & 5.67 & 9.45 & 3.74 & 1.83 & 20.34 & 100 \\
\hline C.V. & 14.10 & 15.20 & 18.06 & 24.21 & 25.81 & 7.22 & 6.73 & \\
\hline C.G.R. & 3.76 & -3.36 & 2.43 & -6.72 & -7.20 & -0.21 & -1.33 & \\
\hline t-value & 5.24 & $3.46^{\star \star}$ & 1.30 & $9.25^{* *}$ & $10.56^{\star \star}$ & 0.29 & $2.80^{*}$ & \\
\hline \multicolumn{8}{|c|}{ Future Projections } & \\
\hline $2015-16$ & 53.85 & 11.98 & 5.93 & 5.66 & 2.12 & 1.79 & 18.67 & \\
\hline
\end{tabular}




\begin{tabular}{|l|l|l|l|l|l|l|l|}
$2016-20$ & 55.63 & 11.37 & 5.95 & 5.02 & 1.85 & 1.78 & 18.39 \\
\hline
\end{tabular}

A view of Table 5.6 showed that on an average, the proportionate share of crop loan outstanding in the total loans outstanding was highest of the order of 43.45 percent, followed by other loans (20.34 percent), RCCL (F) (15.51 percent) and consumer durable loans (9.45 percent) while the lowest proportion to the tune only of 1.83 percent was secured by $\mathrm{CCL}(\mathrm{T})$ outstanding, followed by 3.74 percent by vehicle loans and 5.67 percent by non-farm sector loans outstanding. The growth rate of proportionate share of outstanding crop loan was significantly positive while that of RCC-F, CD loans, vehicle loans and other loans were significantly negative. However, the non-significant growth rates in case of non-farm sector loans and CCL-T outstanding indicated stagnation in these loans. The analysis revealed that there is a scope of significant shift of outstanding advances from RCC-F, consumer durable loans, vehicle loans and other loans towards crop loan. According to the projections, the outstanding crop loans share in total outstanding loans would go as high as 53.85 percent in 2016 and further to 55.63 percent in 2021 . Therefore, there is a dire need to check strictly the fastest increase in crop loan outstanding in DCCB, Amritsar.

THE LUDHIANA CENTRAL COOPERATIVE BANK LTD, LUDHIANA

\begin{tabular}{|c|c|c|c|c|c|c|c|c|}
\hline Year & Crop & RCC-F & NFS & CD & Vehicle & CCL-T & Others & Total \\
\hline $1999-2000$ & 10438.78 & 4246.92 & 669.1 & 1056.63 & 5.18 & 1735.02 & 1027.41 & 19179.04 \\
\hline $2000-01$ & 11031.67 & 4556.53 & 724.94 & 1089.98 & 12.64 & 1933.09 & 1078.73 & 20427.58 \\
\hline 2001-02 & 12641.02 & 4986.44 & 761.02 & 1443.89 & 16.49 & 2830.33 & 2452.46 & 25131.65 \\
\hline $2002-03$ & 15167.76 & 5118.74 & 710.36 & 1639.88 & 21.85 & 4145.81 & 2621.89 & 29426.29 \\
\hline $2003-04$ & 16217.63 & 4960.27 & 758.07 & 1646.79 & 49.94 & 4067.64 & 4099.09 & 31799.43 \\
\hline 2004-05 & 18873.97 & 4581.17 & 640.02 & 1545.59 & 86.53 & 551.85 & 4992.71 & 31271.84 \\
\hline $2005-06$ & 20568.02 & 4352.11 & 554.92 & 1473.97 & 112.24 & 302.98 & 5781.26 & 33145.5 \\
\hline $2006-07$ & 25271 & 4230.36 & 496.97 & 1348.24 & 159.06 & 278.11 & 6108.1 & 37891.84 \\
\hline $2007-08$ & 27315.41 & 4367.21 & 551.13 & 1423.18 & 163.18 & 307.21 & 6634.18 & 40761.5 \\
\hline $2008-09$ & 29421.68 & 4254.43 & 568.23 & 1298.21 & 178.21 & 327.89 & 6823.52 & 42872.17 \\
\hline $2009-10$ & 30272.51 & 4468.87 & 532.51 & 1335.64 & 184.19 & 372.41 & 7154.68 & 44320.81 \\
\hline Average & 19747.22 & 4556.64 & 633.39 & 1391.09 & 89.96 & 1532.03 & 4434.00 & 32384.33 \\
\hline C.V. & 37.22 & 7.09 & 15.26 & 13.97 & 80.25 & 100.03 & 51.95 & 26.45 \\
\hline C.G.R & 12.36 & -0.84 & -3.67 & 1.21 & 43.98 & -23.49 & 22.25 & 8.68 \\
\hline t-value & $23.58^{\star \star}$ & 1.33 & $4.15^{\star \star}$ & 0.85 & $8.44^{* *}$ & $4.41^{\star \star}$ & $6.81^{* *}$ & $12.20^{\star \star}$ \\
\hline & & & 11 & 年 & & & & \\
\hline$a$ & 6584.93 & 4793.44 & 773.54 & 1314.20 & -37.36 & 3294.03 & 353.17 & 17075.95 \\
\hline $\mathrm{b}$ & 2193.72 & -39.47 & -23.36 & 12.82 & 21.22 & -293.67 & 680.14 & 2551.40 \\
\hline \multicolumn{9}{|c|}{ Future Projections } \\
\hline $2015-16$ & 43878.17 & 4122.45 & 376.42 & 1532.14 & 323.38 & -1698.36 & 11915.55 & 60449.75 \\
\hline $2020-21$ & 54846.77 & 3925.10 & 259.62 & 1596.24 & 429.48 & -3166.71 & 15316.25 & 73206.75 \\
\hline \multicolumn{9}{|c|}{$\begin{array}{l}\text { \%change over 2009- } \\
10\end{array}$} \\
\hline $2015-16$ & 44.94 & -7.75 & -29.31 & 14.71 & 75.57 & -556.05 & 66.54 & 36.39 \\
\hline $2020-21$ & 81.18 & -12.17 & -51.25 & 19.51 & 133.17 & -950.33 & 114.07 & 65.17 \\
\hline
\end{tabular}


According to the analysis shown in Table 5.7, the total loans outstanding increased from Rs. 19179.04 lacs in 2000 to Rs. 445320.81 lacs in 2010, registering a compound growth rate of 8.68 per cent per annum in DCCB, Ludhiana. The outstanding in crop loan, vehicle loan and other loans increased at significantly positive growth rate i.e. 12.36 percent, 43.98 percent and 22.25 percent respectively while the outstanding in non-farm sector loan and cash credit limit to traders declined significantly at the rate of -3.15 percent and 23.49 percent respectively, compounded annually. However, there was statistically no significant change in outstanding in RCCL (F) and consumer durable loans.

The existing trend showed that the total loans outstanding would increase to the level of Rs. 60449.75 lacs in 2016 i.e. 36.39 percent higher than 2010 and further to Rs. 73206.75 lacs in 2021 i.e. 65.17 percent higher than 2010. This future increase in total loans outstanding might be attributed to the highly significant increase in crop loan liabilities and other loans outstanding while the outstanding in RCC-F, NFS and CCL (T) would fall drastically in the near future.

\begin{tabular}{|c|c|c|c|c|c|c|c|c|}
\hline Year & Crop & RCC-F & NFS & CD & Vehicle & CCL-T & Others & Total \\
\hline $1999-2000$ & 54.43 & 22.14 & 3.49 & 5.51 & 0.03 & 9.05 & 5.36 & 100 \\
\hline $2000-01$ & 54.00 & 22.31 & 3.55 & 5.34 & 0.06 & 9.46 & 5.28 & 100 \\
\hline 2001-02 & 50.30 & 19.84 & 3.03 & 5.75 & 0.07 & 11.26 & 9.76 & 100 \\
\hline $2002-03$ & 51.54 & 17.40 & 2.41 & 5.57 & 0.07 & 14.09 & 8.91 & 100 \\
\hline $2003-04$ & 51.00 & 15.60 & 2.38 & 5.18 & 0.16 & 12.79 & 12.89 & 100 \\
\hline $2004-05$ & 60.35 & 14.65 & 2.05 & 4.94 & 0.28 & 1.76 & 15.97 & 100 \\
\hline $2005-06$ & 62.05 & 13.13 & 1.67 & 4.45 & 0.34 & 0.91 & 17.44 & 100 \\
\hline $2006-07$ & 66.69 & 11.16 & 1.31 & 3.56 & 0.42 & 0.73 & 16.12 & 100 \\
\hline 2007-08 & 67.01 & 10.71 & 1.35 & 3.49 & 0.40 & 0.75 & 16.28 & 100 \\
\hline $2008-09$ & 68.63 & 9.92 & 1.33 & 3.03 & 0.42 & 0.76 & 15.92 & 100 \\
\hline $2009-10$ & 68.30 & 10.08 & 1.20 & 3.01 & 0.42 & 0.84 & 16.14 & 100 \\
\hline Average & 59.48 & 15.18 & 2.16 & 4.53 & 0.24 & 5.67 & 12.73 & 100 \\
\hline C.V. & 12.49 & 30.92 & 40.86 & 23.52 & 68.47 & 98.50 & 36.15 & \\
\hline C.G.R. & 3.39 & -8.76 & -11.36 & -6.87 & 32.01 & -29.63 & 12.49 & \\
\hline $\mathrm{t}$-value & $5.46^{* *}$ & $19.76^{\star *}$ & $15.08^{* *}$ & $8.25^{\star \star}$ & $7.26^{\star *}$ & $6.40^{\star \star}$ & $4.94^{* *}$ & \\
\hline \multicolumn{8}{|c|}{ Future Projections } & \\
\hline $2015-16$ & 72.59 & 6.82 & 0.62 & 2.53 & 0.53 & -2.81 & 19.71 & \\
\hline $2016-20$ & 74.92 & 5.36 & 0.35 & 2.18 & 0.59 & -4.33 & 20.92 & \\
\hline
\end{tabular}

Table 5.8 indicates that the proportionate share of different types of loans outstanding increased significantly from 54.43 percent in 2000 to 68.30 percent in 2010 in case of crop loan outstanding registering a significant growth rate of 3.39 per cent per annum.. On the other hand, the proportion of crop loan outstanding would be 72.59 percent in 2016 and 74.92 percent in 2021 while that of other loans outstanding would be 19.71 percent in 2016 and 20.92 percent in 2021. Thus the bank should concentrate on recovery of crop loan and other loans.

\section{ZONE-III}

THE MANSA CENTRAL COOPERATIVE BANK LTD, MANSA

\begin{tabular}{|l|c|c|c|c|c|c|c|c|}
\hline \multicolumn{7}{|c|}{ Table 5.9: Trends in different types of absolute advances outstanding in DCCB Mansa in Zone-III } \\
\hline Year & Crop & RCC-F & NFS & CD & Vehicle & CCL-T & Others & Total \\
\hline $1999-2000$ & 4769.19 & 890.02 & 160.79 & 85.61 & & 18.94 & 1102.65 & 7027.2 \\
\hline $2000-01$ & 5438.5 & 1037.74 & 159.07 & 144.98 & 7.01 & 37.31 & 932.53 & 7757.14 \\
\hline $2001-02$ & 5234.06 & 1299.52 & 218.18 & 277.66 & 25.00 & 73.11 & 2274.95 & 9402.48 \\
\hline $2002-03$ & 6538.23 & 1356.4 & 334.03 & 563.99 & 20.61 & 303.48 & 1801.07 & 10917.81 \\
\hline $2003-04$ & 6657.47 & 1257.51 & 599.73 & 809.48 & 34.74 & 232.3 & 2931.39 & 12522.62 \\
\hline
\end{tabular}




\begin{tabular}{|c|c|c|c|c|c|c|c|c|}
\hline 2004-05 & 8613.77 & 1286.78 & 949.65 & 1042.76 & 69.62 & 478.92 & 3420.31 & 15861.81 \\
\hline $2005-06$ & 11099.49 & 2068.88 & 632.57 & 1011.95 & 83.92 & 530.38 & 3996.05 & 19423.24 \\
\hline $2006-07$ & 13700.52 & 2543.61 & 595.47 & 958.65 & 111.56 & 510 & 4063.39 & 22483.2 \\
\hline $2007-08$ & 14223.56 & 2671.18 & 721.14 & 1023.14 & 113.37 & 521 & 4256.21 & 23529.6 \\
\hline $2008-09$ & 15878.21 & 2832.51 & 632.18 & 1056.21 & 121.62 & 578.24 & 4461.18 & 25560.15 \\
\hline $2009-10$ & 16213.34 & 3114.68 & 743.52 & 998.25 & 137.54 & 562.13 & 4513.34 & 26282.8 \\
\hline Average & 9851.49 & 1850.80 & 522.39 & 724.79 & 72.50 & 349.62 & 3068.46 & 16433.46 \\
\hline C.V. & 45.58 & 43.78 & 50.55 & 53.25 & 66.06 & 64.03 & 43.84 & 44.53 \\
\hline C.G.R & 15.02 & 13.78 & 17.75 & 26.00 & 35.46 & 38.30 & 16.84 & 15.60 \\
\hline t-value & $13.75^{\star \star}$ & $9.71^{* \star}$ & $4.26^{\star *}$ & $4.35^{\star \star}$ & $6.29^{\star \star}$ & $4.63^{* *}$ & $6.03^{* *}$ & $16.41^{* \star}$ \\
\hline \multicolumn{9}{|c|}{ Trend coefficients } \\
\hline$a$ & 1957.96 & 454.27 & 147.63 & 100.99 & -12.82 & -28.62 & 739.31 & 3358.72 \\
\hline $\mathrm{b}$ & 1315.59 & 232.76 & 62.46 & 103.97 & 15.51 & 63.04 & 388.19 & 2181.52 \\
\hline \multicolumn{9}{|l|}{ Future Projections } \\
\hline $2015-16$ & 24322.99 & 4411.19 & 1209.45 & 1868.48 & 250.85 & 1043.06 & 7338.54 & 40444.56 \\
\hline $2020-21$ & 30900.94 & 5574.99 & 1521.75 & 2388.33 & 328.40 & 1358.26 & 9279.49 & 51352.16 \\
\hline \multicolumn{9}{|c|}{ \%change over 2009-10 } \\
\hline $2015-16$ & 50.02 & 41.63 & 62.67 & 87.18 & 82.38 & 85.55 & 62.60 & 53.88 \\
\hline $2020-21$ & 90.59 & 78.99 & 104.67 & 139.25 & 138.77 & 141.63 & 105.60 & 95.38 \\
\hline
\end{tabular}

Table 5.9 reveals that the total loans outstanding in DCCB, Mansa increased from Rs. 7027.21 lacs in 2000 to Rs. 26282.80 lacs in 2010 , registering a highly significant growth rate of 15.60 per cent compounded annually. The highest growth rate was recorded in case of CCL-T outstanding (38.30\%), followed by vehicle loans (35.46). There was in general significant growth of all types of loans outstanding. The increase in CCL (T) outstanding and consumer durable loans outstanding was found to be significant at the rate of 38.30 percent and 35.46 percent respectively, followed by 26.00 percent in case of CD loans, 17.75 percent in case of NFS loans outstanding and 16.84 percent in case of other loans outstanding. However, the compound growth rates of crop loan and RCCL (F) outstanding were also highly significant i.e. 15.02 percent and 13.78 percent respectively.

The existing trends revealed that the total loan outstanding would be at the level of Rs. 40444.56 lacs in 2016 and further to Rs. 51352.16 lacs in 2021. All types of loans outstanding are estimated to increase in future in a significant manner which may put question on the financial viability of this bank. The increase in crop loan, RCCL (F) and other loans outstanding is more serious than others.

Trends in Proportionate Share of Different Types of Advances Outstanding:

Table 5.10: Trends in proportionate share of different types of advances outstanding in DCCB Mansa in Zone-III

\begin{tabular}{|l|c|c|c|c|c|c|c|c|}
\hline Year & Crop & RCC-F & NFS & CD & Vehicle & CCL-T & Others & Total \\
\hline $1999-2000$ & 67.87 & 12.67 & 2.29 & 1.22 & & 0.27 & 15.69 & 100 \\
\hline $2000-01$ & 70.11 & 13.38 & 2.05 & 1.87 & 0.09 & 0.48 & 12.02 & 100 \\
\hline $2001-02$ & 55.67 & 13.82 & 2.32 & 2.95 & 0.27 & 0.78 & 24.20 & 100 \\
\hline $2002-03$ & 59.89 & 12.42 & 3.06 & 5.17 & 0.19 & 2.78 & 16.50 & 100 \\
\hline $2003-04$ & 53.16 & 10.04 & 4.79 & 6.46 & 0.28 & 1.86 & 23.41 & 100 \\
\hline $2004-05$ & 54.31 & 8.11 & 5.99 & 6.57 & 0.44 & 3.02 & 21.56 & 100 \\
\hline $2005-06$ & 57.15 & 10.65 & 3.26 & 5.21 & 0.43 & 2.73 & 20.57 & 100 \\
\hline $2006-07$ & 60.94 & 11.31 & 2.65 & 4.26 & 0.50 & 2.27 & 18.07 & 100 \\
\hline $2007-08$ & 60.45 & 11.35 & 3.06 & 4.35 & 0.48 & 2.21 & 18.09 & 100 \\
\hline
\end{tabular}




\begin{tabular}{|c|c|c|c|c|c|c|c|c|}
\hline 2008-09 & 62.12 & 11.08 & 2.47 & 4.13 & 0.48 & 2.26 & 17.45 & 100 \\
\hline $2009-10$ & 61.69 & 11.85 & 2.83 & 3.80 & 0.52 & 2.14 & 17.17 & 100 \\
\hline Average & 60.30 & 11.52 & 3.16 & 4.18 & 0.37 & 1.89 & 18.61 & 100 \\
\hline C.V. & 8.74 & 13.95 & 37.72 & 40.57 & 40.82 & 50.38 & 19.16 & \\
\hline C.G.R. & -0.50 & -1.58 & 1.85 & 8.99 & 17.18 & 19.63 & 1.08 & \\
\hline t-value & 0.60 & 1.16 & 0.57 & 1.90 & $4.22^{\star \star}$ & $2.96^{*}$ & 0.54 & \\
\hline \multicolumn{8}{|c|}{ Future Projections } & \\
\hline $2015-16$ & 60.14 & 10.91 & 2.99 & 4.62 & 0.62 & 2.58 & 18.14 & \\
\hline $2016-20$ & 60.17 & 10.86 & 2.96 & 4.65 & 0.64 & 2.64 & 18.07 & \\
\hline
\end{tabular}

A perusal of Table 5.10 showed that the crop loan outstanding secured the major share in total loans outstanding. It was on the average, 60.30 percent, which, according to the existing trend, would not decline significantly in future. There is a scope for proportionate share of crop loans outstanding to remain stagnant. Similar was the pattern observed in case of RCC-F, non-farm sector outstanding, CD loans and other loans. On the other hand, the increase in the proportionate share of vehicle loans (17.18 percent) and CCL-T loans (19.63 percent) outstanding came to be significant and would further increase in future. The serious concern area remains the recovery of crop loan, RCCL (F) and other loan outstanding in DCCB, Mansa.

THE BATHINDA CENTRAL COOPERATIVE BANK LTD, BATHINDA

\begin{tabular}{|c|c|c|c|c|c|c|c|c|}
\hline Year & Crop & RCC-F & NFS & CD & Vehicle & CCL-T & Others & Total \\
\hline $1999-2000$ & 8851.48 & 1721.34 & 450.66 & 280.51 & 38.15 & 507.04 & 597.16 & 12446.34 \\
\hline $2000-01$ & 9765.87 & 2467.76 & 442.97 & 277.52 & 42.18 & 456.42 & 1686.11 & 15138.83 \\
\hline 2001-02 & 10594.35 & 3282.54 & 530.42 & 328.8 & 46.02 & 447.19 & 1935.2 & 17164.52 \\
\hline $2002-03$ & 12283.72 & 3300.31 & 617.64 & 459.22 & 44.13 & 727.42 & 2285.84 & 19718.28 \\
\hline 2003-04 & 12110.71 & 3352.68 & 631.14 & 625.72 & 43.65 & 768.08 & 4233.04 & 21765.02 \\
\hline 2004-05 & 12622.71 & 3474.56 & 628.54 & 853.92 & 45.58 & 759.44 & 7332.72 & 25717.47 \\
\hline $2005-06$ & 15835.41 & 3888.96 & 619.13 & 889.33 & 98.32 & 870.64 & 7909.44 & 30111.23 \\
\hline $2006-07$ & 24560.22 & 4329.39 & 685.04 & 875.27 & 64.8 & 735.06 & 5367.13 & 36616.91 \\
\hline $2007-08$ & 25763.21 & 4557.14 & 713.24 & 887.51 & 77.23 & 713.78 & 5465.21 & 38177.32 \\
\hline 2008-09 & 27213.52 & 4712.19 & 721.72 & 854.11 & 78.15 & 884.19 & 5748.12 & 40212 \\
\hline $2009-10$ & 30441.78 & 5334.68 & 729.18 & 837.62 & 82.61 & 876.23 & 5834.29 & 44136.39 \\
\hline Average & 17276.63 & 3674.69 & 615.43 & 651.78 & 60.07 & 704.14 & 4399.48 & 27382.21 \\
\hline C.V. & 46.47 & 28.27 & 16.51 & 40.54 & 34.70 & 23.11 & 55.33 & 40.42 \\
\hline C.G.R & 14.19 & 9.44 & 5.07 & 14.18 & 8.98 & 6.50 & 21.86 & 13.78 \\
\hline t-value & $10.69^{* *}$ & $7.45^{\star \star}$ & $7.13^{* *}$ & $5.63^{\star *}$ & $4.63^{* *}$ & $4.11^{* *}$ & $3.96^{* *}$ & $21.77^{\star *}$ \\
\hline \multicolumn{9}{|c|}{ Trend coefficients } \\
\hline$a$ & 3557.01 & 1949.45 & 442.03 & 222.84 & 29.76 & 460.06 & 970.60 & 7631.75 \\
\hline $\mathrm{b}$ & 2286.60 & 304.21 & 28.90 & 71.49 & 5.05 & 40.68 & 571.48 & 3308.41 \\
\hline \multicolumn{9}{|c|}{ Future Projections } \\
\hline $2015-16$ & 42429.21 & 7121.02 & 933.33 & 1438.17 & 115.61 & 1151.62 & 10685.76 & 63874.72 \\
\hline $2020-21$ & 53862.21 & 8642.07 & 1077.83 & 1795.62 & 140.86 & 1355.02 & 13543.16 & 80416.77 \\
\hline \multicolumn{9}{|c|}{ \%change over 2009-10 } \\
\hline $2015-16$ & 39.38 & 33.49 & 28.00 & 71.70 & 39.95 & 31.43 & 83.15 & 44.72 \\
\hline
\end{tabular}


It is clear from the Table 5.11 that total loans outstanding increased from Rs. 12446.34 lacs in 2000 to Rs. 44136.39 lacs in 2010 , depicting a highly significant increase at the compound growth rate of 13.78 per cent per annum. The rate of growth was highly significant as the calculated t-value came to be as high as 21.77 . The table further revealed that the increase in all type of loans outstanding was significant. The rate of increase was found to be the highest of the order of 21.86 percent compounded annually in case of outstanding in other loans (housing, personal, etc.) followed by 14.19 percent in crop loan, 14.18 percent in consumer durable loans and 9.44 percent in case of RCCL (F), while the lowest rate of increase to the tune of 5.07 percent was found in case of outstanding in non-farm sector loans, followed by 6.50 percent in CCL (T) and 8.98 percent in vehicle loans.

Keeping in view the existing trend, the total loan outstanding would increase to the level of Rs. 63874.72 in 2016 i.e. 44.72 percent higher over 2010 and further to Rs. 80416.77 lacs in 2021 i.e. 82.20 percent higher over 2010. The regression coefficient of time came to be positive in all the equations developed for different types of loans outstanding. This indicated that all types of loans outstanding would increase further in future. The projected values of different types of loans outstanding shown in the table 5.11 clearly indicated this trend.

Trends in Proportionate Share of Different Types of Advances Outstanding:

\begin{tabular}{|c|c|c|c|c|c|c|c|c|}
\hline Year & Crop & RCC-F & NFS & $\mathrm{CD}$ & Vehicle & CCL-T & Others & Total \\
\hline $1999-2000$ & 71.12 & 13.83 & 3.62 & 2.25 & 0.31 & 4.07 & 4.80 & 100 \\
\hline $2000-01$ & 64.51 & 16.30 & 2.93 & 1.83 & 0.28 & 3.01 & 11.14 & 100 \\
\hline $2001-02$ & 61.72 & 19.12 & 3.09 & 1.92 & 0.27 & 2.61 & 11.27 & 100 \\
\hline 2002-03 & 62.30 & 16.74 & 3.13 & 2.33 & 0.22 & 3.69 & 11.59 & 100 \\
\hline 2003-04 & 55.64 & 15.40 & 2.90 & 2.87 & 0.20 & 3.53 & 19.45 & 100 \\
\hline 2004-05 & 49.08 & 13.51 & 2.44 & 3.32 & 0.18 & 2.95 & 28.51 & 100 \\
\hline $2005-06$ & 52.59 & 12.92 & 2.06 & 2.95 & 0.33 & 2.89 & 26.27 & 100 \\
\hline 2006-07 & 67.07 & 11.82 & 1.87 & 2.39 & 0.18 & 2.01 & 14.66 & 100 \\
\hline 2007-08 & 67.48 & 11.94 & 1.87 & 2.32 & 0.20 & 1.87 & 14.32 & 100 \\
\hline 2008-09 & 67.68 & 11.72 & 1.79 & 2.12 & 0.19 & 2.20 & 14.29 & 100 \\
\hline $2009-10$ & 68.97 & 12.09 & 1.65 & 1.90 & 0.19 & 1.99 & 13.22 & 100 \\
\hline Average & 62.56 & 14.13 & 2.49 & 2.38 & 0.23 & 2.80 & 15.41 & 100 \\
\hline C.V. & 11.51 & 17.36 & 27.14 & 20.09 & 23.44 & 26.66 & 44.78 & \\
\hline C.G.R. & 0.36 & -3.81 & -7.67 & 0.35 & -4.27 & -6.38 & 7.11 & \\
\hline t-value & 0.30 & $3.76^{* *}$ & $11.37^{\star *}$ & 0.18 & $2.54^{*}$ & $4.35^{\star *}$ & 1.57 & \\
\hline \multicolumn{8}{|c|}{ Future Projections } & \\
\hline $2015-16$ & 66.43 & 11.15 & 1.46 & 2.25 & 0.18 & 1.80 & 16.73 & \\
\hline $2016-20$ & 66.98 & 10.75 & 1.34 & 2.23 & 0.18 & 1.68 & 16.84 & \\
\hline
\end{tabular}

The analysis shown in the Table 5.12 indicated that, on an average, the highest share i.e. 62.56 percent of total loans outstanding was secured by crop loans only. This was followed by 15.41 percent in case of other loans and 14.13 percent in case RCC-F. All other types of loans outstanding i.e. non-farm sector, consumer durable loans, vehicle loans and $\mathrm{CCL}(\mathrm{T})$, together accounted for only 7.90 percent of the total loans outstanding. The share of outstanding in RCC-F, NFS loans, vehicle loans and CCL-T decreased significantly through 2000-2010 which would further decline in future while the share of crop loans, CD loans and other loans remained stagnant. Thus, DCCB, Bathinda should focus on the recovery these types of loans, and particularly keeping in view the highest quantum of crop loans outstanding, the bank should make stringent efforts for the recovery of these loans.

\section{CONCLUSION}


The rate of growth of total loans outstanding increased at a faster rate in DCCBs in Zone-III, followed by Zone-II and Zone-I. This pattern is in direct relationship with the farm size in different zones. The average farm size is the largest in Zone-III, followed by Zone-II while it is the smallest in Zone-I.

\section{REFERENCES}

1. Acharya, V.V; Hasan, I. and Saunders, A.(2002), 'Should banks be diversified? Evidence from individual bank loan portfolios', BIS Working Papers, No.118, September.

2. Grover, F. (1985), 'What is Co-operation? The Philosophy of Cooperation and its Relationship to Cooperative Structure and Operations', Accessed from www.wisc.edu/uwcc/into/ocpap/groves.html, 1985.

3. Kumar, Ashok. Singh, C.B: A Study Of IRDP Loan Overdues under Milch Animal Scheme, The Indian Cooperative Review, Vol XXXVII, No 3, Jan 2000, pp 179-185.

4. MANJIT SINGH, PARNEET KAUR,"Trends In the Deposits of Credit Cooperatives in Punjab after Financial Sector Reforms “, VOL. - I, NO. - 2, JAN-2011, Management Convergence, Pg 10-21

5. NABARD: Developments In Cooperative Banking (accessed from www.nabard.org)

6. Reddy, C.R: Overdues Appraisal and Management in Banking, I.C.R, XXIII (!), 1985, pp 77-93.

7. Shah and Mishra (1993), 'Analyzing under Performance in Indian Cooperatives', Enterprises Development, Vol. 3, No. 1.

8. Shah, D. (2002), 'Dwindling Viability of Primary Agricultural Co-operative Credit Societies during Period of Institutional Reforms: An Evidence from Maharashtra', Indian Journal of Agricultural Economics, Vol. 57, No. 3, July-Sep

9. Singh, Rajinder. And Singh, H.P: A Study of Overdues in Cooperatives, I.C.R, 17(1), 1979, pp 73-79.

10. Visvanath, A.R: An Analysis of Performance of Agricultural Credit Problems in India, The Indian Cooperative Review, Vol XXXIX, No 1, July 2001, pp 54-61. 